Int. J. Dev. Biol. 48: 1061-1064 (2004)

doi: $10.1387 / \mathrm{ijdb} .041925 \mathrm{gk}$

Special Contribution

\title{
The generation of insulin-producing cells from embryonic stem cells - a discussion of controversial findings
}

\author{
GABRIELA KANIA, PRZEMYSLAW BLYSZCZUK and ANNA M. WOBUS* \\ In Vitro Differentiation Group, IPK Gatersleben, Germany
}

\begin{abstract}
The derivation of insulin-producing cells from embryonic stem (ES) cells has been controversially described. Whereas several authors showed successful differentiation of mouse ES cells into islet-like clusters, others could not confirm the results. Here, we present a detailed comparison of the various strategies used to generate pancreatic cells with respect to protocols and differentiation factors and give an explanation of the contradictory findings. It is suggested that the selection or enrichment of ES-derived nestin-positive cells should be avoided, since these cells are already committed to a neural fate before pancreatic differentiation is induced.
\end{abstract}

KEY WORDS: mouse embryonic stem cell, differentiation, C-peptide, insulin-producing cell, nestin

\section{Introduction}

The generation of insulin-producing cells from differentiated embryonic stem (ES) cells by a four-step protocol was described some years ago (Lumelsky et al., 2001), but subsequent studies could not confirm these results. Instead, it was demonstrated that: (i) insulin immunoreactivity could occur as a consequence of insulin uptake from the medium (Rajagopal et al., 2003), (ii) neuronal cells could be formed (Rajagopal et al., 2003; Hansson et al., 2004; Sipione et al., 2004), or (iii) insulin could be released artifactually from differentiated ES cells (Rajagopal et al., 2003; Hansson et al., 2004). Other authors, using modified protocols with or without Pax4 transgene expression (Blyszczuk et al., 2003; Blyszczuk et al., 2004) or addition of a specific PI3K inhibitor (Hori et al., 2002) reported the generation of pancreatic cells characterized by glucose-responsive insulin release and some functional properties of pancreatic cells. However, until now, there has been no explanation of these contradictory findings and a critical discussion of the pancreatic differentiation protocols is lacking.

\section{Comparison of the differentiation systems}

In Protocols 1 to 4 (Fig. 1), embryoid body (EB) outgrowths were cultured in medium supplemented by insulin, transferrin, selenium and fibronectin (= ITSFn). Culture in ITSFn medium was originally developed to enrich nestinpositive cells before induction into the neuronal lineage
(Okabe et al., 1996). In Protocols 1 to 3 , proliferation of nestin-positive cells was supported by addition of bFGF (= FGF-2), but after the induction of pancreatic differentiation the FGF-2 was removed. In Protocol 2 (Miyazaki et al., 2004), pancreatic differentiation had already been induced at stage 4 (with additional factors), in contrast to Protocols 1 and 3 (see Fig. 1).

In Protocols 4 (Blyszczuk et al., 2003) and 5 (Blyszczuk et al., 2004), the culture medium was not supplemented with FGF-2 and the differentiation time was extended to between 28 and 32 days. These cells showed insulin transcripts and C-peptide/insulin co-expression (Blyszczuk and Wobus, 2004; Blyszczuk et al., 2004). ES cells constitutively expressing Pax4 showed insulin-secretory granules (Blyszczuk et al., 2003), ion channel activity of embryonal beta cells and normalization of blood glucose level after transplantation into diabetic mice (Blyszczuk et al., 2004). These properties were not observed in cells which differentiated according to Protocols 1 and 3 (Fig. 1). This led us to question the role of FGF-2 in pancreatic differentiation of ES cells in vitro.

\section{Pancreatic vs. neural differentiation}

Following differentiation according to Protocols 1,2 and 3 , both pancreatic and neuronal cells were generated from ES cells (Lumelsky et al., 2001; Hori et al., 2002; Sipione et al., 2004; Rajagopal et al., 2003; Hansson et al., 2004; Miyazaki et al., 2004). As mentioned above, culture in

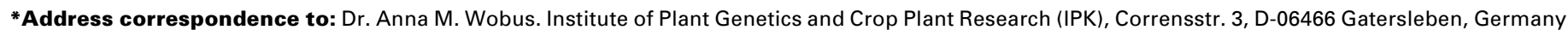
Fax: +49-3-9482-5481. e-mail: wobusam@ipk-gatersleben.de
} 


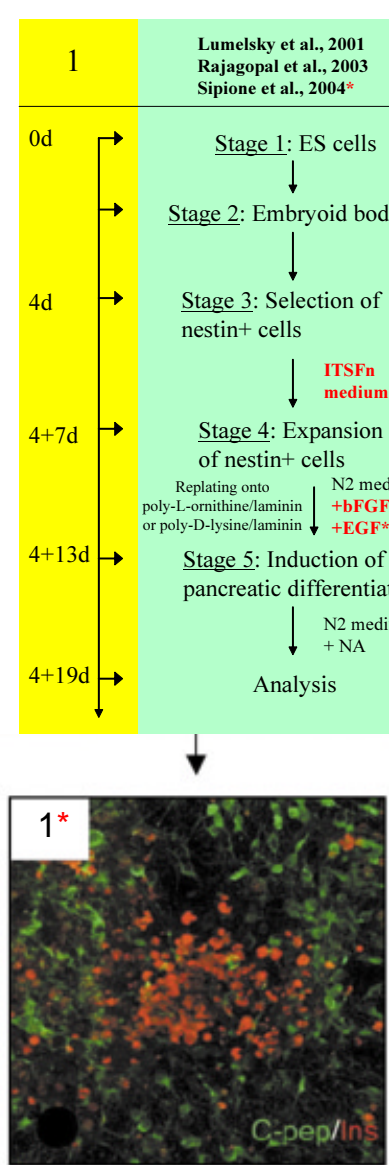

Sipione et al., 2004
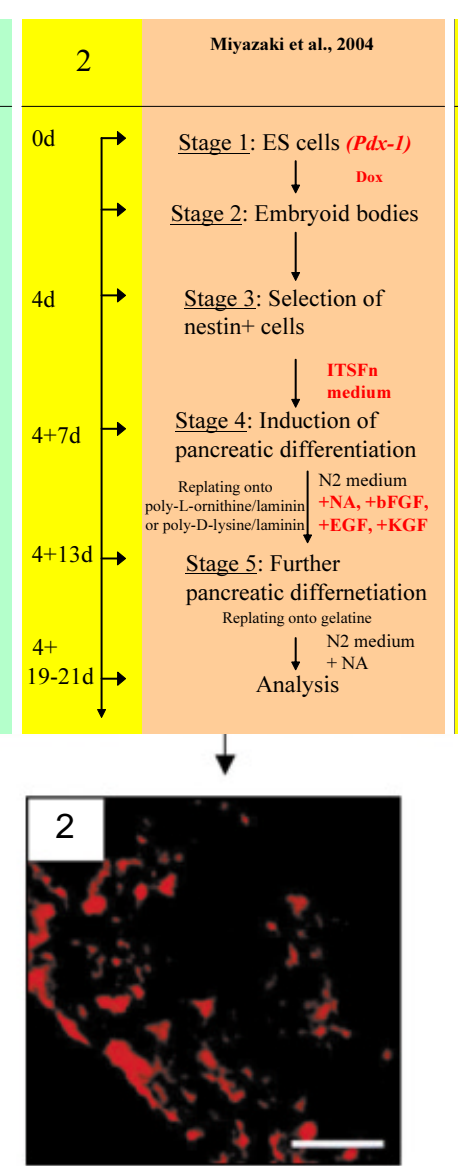

Bar $=50 \mu \mathrm{m}$

Miyazaki et al., 2004

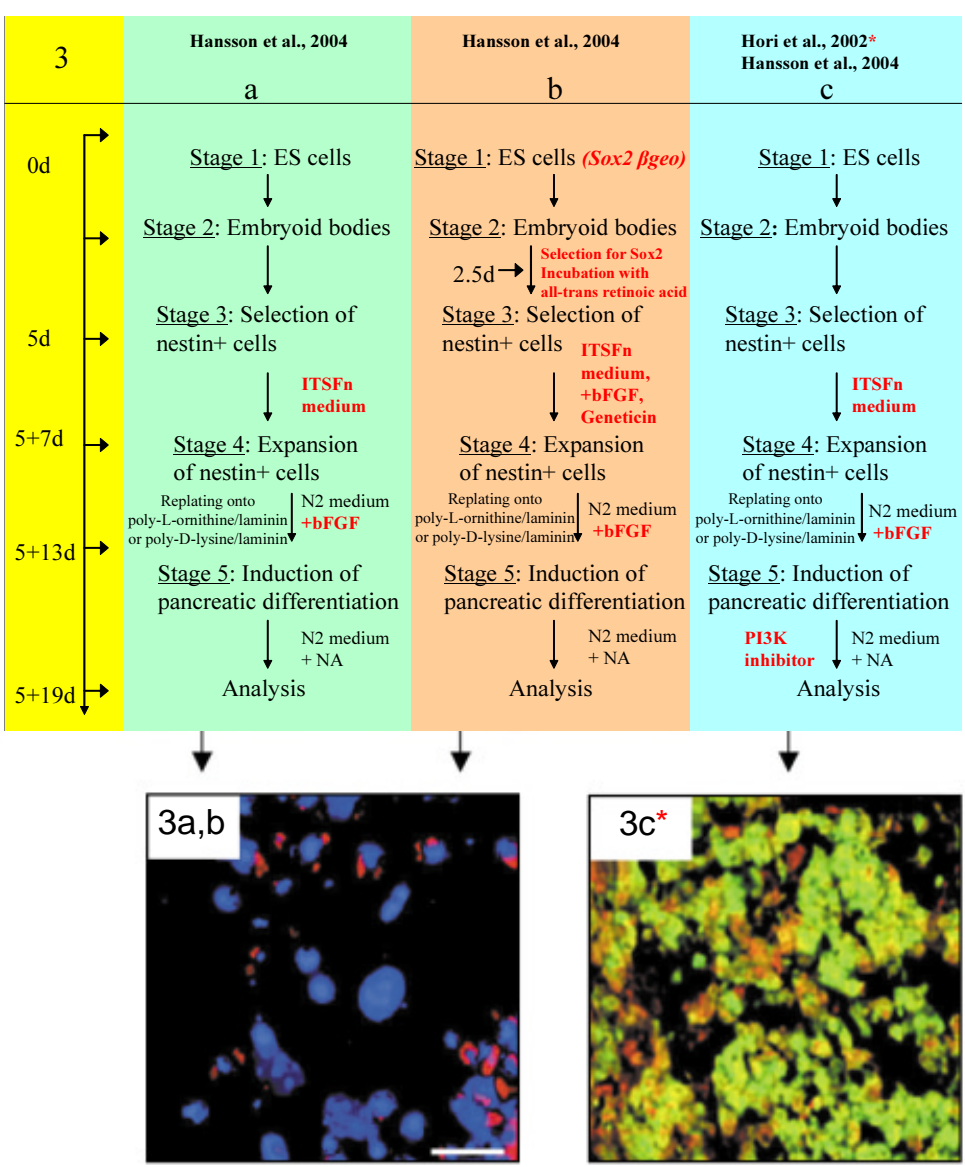

Bar $=20 \mu \mathrm{m}$

Hansson et al., 2004
Hori et al., 2002
ITSFn- and FGF-2-supplemented medium induced commitment of cells to a neuronal fate. Also, the culture of early ES-derived cells, with a high concentration of all-trans retinoic acid (RA, $10^{-6} \mathrm{~mol}$, Protocol $3 \mathrm{~b}$ ), definitely promotes neuronal differentiation of ES cells (Wobus et al., 1994), whereas constitutive expression of Sox 2 inhibited neuronal differentiation, but maintained properties of neural progenitors (Graham et al., 2003). When cultured in the presence of FGF-2, also cells expressing the pancreatic developmental control gene $p d x-1$ differentiated into the neuronal lineage (Miyazaki et al., 2004).

There are several indications of a close relationship between neural and pancreatic cell types. It is well known that the transcription factors Isl-1, Ngn3, Pax6 and Pax4, neuropeptide-processing enzymes and glucose transporters are expressed in both cultured neural and endocrine pancreatic cells (Edlund, 1998; Edlund, 2001). Recently, multipotent precursor cells have been clonally isolated from adult pancreatic tissue and, when induced to differentiate, the cells developed into neural and pancreatic cell types, including neuronal and glial cells, pancreatic endocrine beta-, alpha- and delta-cells and pancreatic exocrine and stellate cells (Seaberg et al., 2004). These findings suggest a close relationship of neural and pancreatic cells. We therefore speculate that the addition of ITSFn and FGF-2 before induction of pancreatic differentiation would induce commitment of cells to a neuronal fate. However, once the cells have become committed to a neuronal fate, the procedure for induction of pancreatic differentiation eventually would activate apoptotic pathways.

FGF-2 is known to play a critical role in development in vivo (e.g. Joseph-Silverstein et al., 1989; Kalcheim and Neufeld, 1990). In vitro, FGF-2 supports the proliferation and differentiation of brain-derived neural progenitor cells (Gritti et al., 1995). FGF-2 is used to form neurospheres from adult neural stem cells (Reynolds and Weiss, 1992) and to generate nestin-positive cells from ES cells (Okabe et al., 1996). A recent study shows that neural stem cells cultured as neurospheres in the presence of FGF-2 lose their original fate specification, resulting in modified transcript levels of regulatory genes (Hack et al., 2004).

During pancreatic development, the prepancreatic endoderm is sensitive to FGF-2 concentration (Deutsch et al., 2001). Whereas higher doses elicit a hepatic program, lower doses or lack of FGF-2 allow pancreatic differentiation (Kim and MacDonald, 2002). This suggests that local concentrations of FGF-2 determine the choice between a hepatic or a pancreatic fate (Rossi et al., 2001) or more 

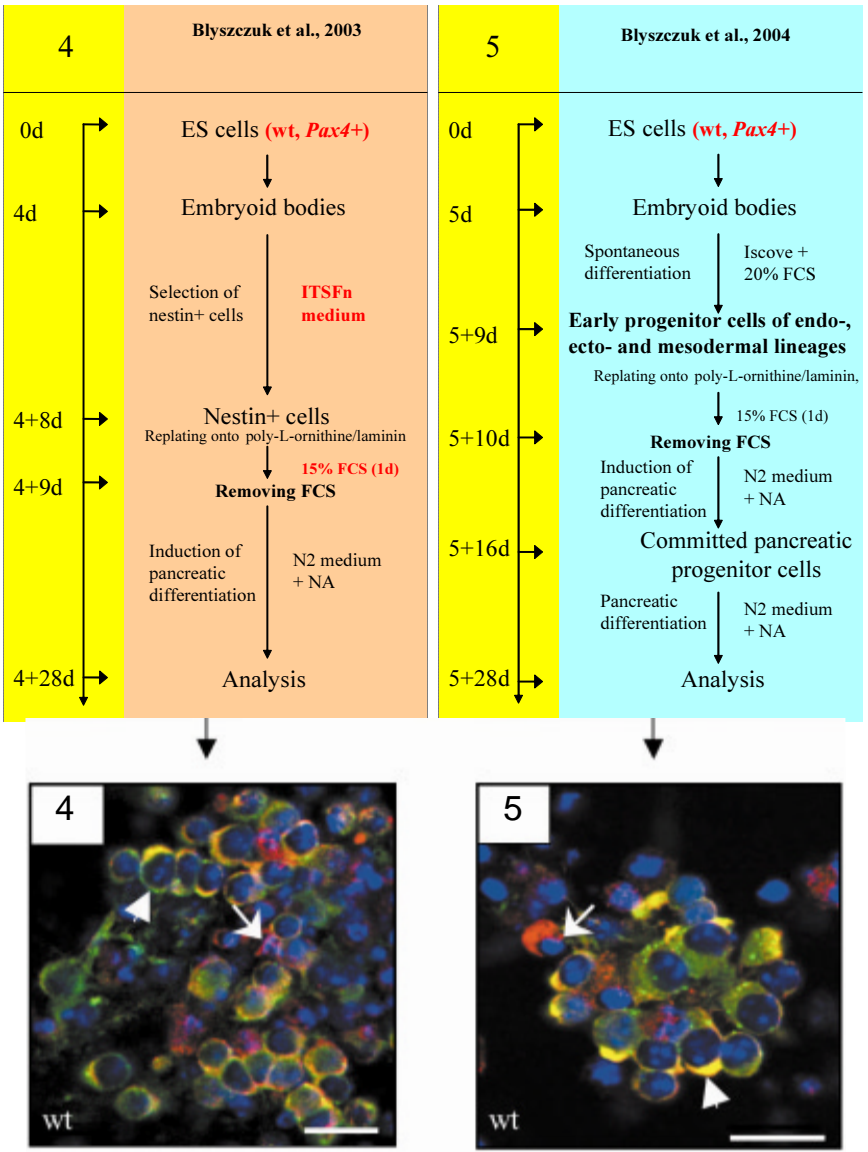

$\mathrm{Bar}=20 \mu \mathrm{m}$

Blyszczuk et al., 2003

Blyszczuk and Wobus, 2004

generally, that different progenitor cells respond differently to FGF-2.

Protocol 5 was designed to avoid the use of ITSFn and FGF-2, so that selection or enrichment of specific cell types before induction of pancreatic differentiation would not occur. ES cells spontaneously differentiated via EBs into
Fig. 1. Comparison of Protocols 1 to 5 used for the differentiation of ES cells into insulin-producing islet-like clusters. Images shown below show immunofluorescence labeling of insulin or C-peptide/insulin according to the following protocols: (Protocol 1) Based on Lumelskiet al. (2001). No coexpression of C-peptide (green) with insulin (red) was found; instead, there are distinct cell populations positive either for $C$-peptide or for insulin (see Sipione et al., 2004). (Protocol 2) Based on Miyazakiet al. (2004). After pancreatic differentiation at stage 5, C-peptide-positive clusters (red) were detected, but no double labeling with insulin was obtained (Dox, doxycycline). (Protocol 3a,b) Based on Hansson et al. (2004). No C-peptide staining was found and insulin staining (red) was restricted to apoptotic cells. (Protocol 3c) Based on Hori et al. (2002). C-peptide (green)/insulin (red) co-expression (yellow) was found after the addition of the PI3K inhibitor to the differentiation medium, contrary to Hansson et al. (2004). (Protocol 4) Based on Blyszczuket al. (2003). Co-expression of C-peptide (green) with insulin (red) was observed. Arrowheads indicate C-peptide/ insulin co-expression (yellow), whereas arrows indicate insulin-positive and C-peptide-negative cells (red) with small and condensed nuclei, suggesting apoptosis. These cells may represent those that take up insulin from the medium (see Blyszczuk and Wobus, 2004). (Protocol 5) Based on Blyszczuk et al., (2004). Coexpression of C-peptide (green) with insulin (red) was demonstrated. Arrowheads indicate $C$-peptide/insulin co-expression (yellow), whereas arrows indicate insulin-positive and C-peptidenegative cells (red). These cells may represent apoptotic cells, but the number of apoptotic cells in the islet-like structures was reduced compared with Protocol 4.

multi-lineage progenitor cells and following induction of pancreatic differentiation by serum-free medium containing niacinamide and laminin, functional beta-like cells were generated (Fig. 1, Protocol 5; Table 1; Blyszczuk et al., 2004).

\section{Insulin uptake and induction of apoptosis}

The selection of nestin-positive cells according to Protocol 1 resulted in the activation of apoptotic pathways (Rajagopal et al., 2003; Miyazaki et al., 2004) and the ES-derived cells were Cpeptide-negative and showed artifactual insulin release (Rajagopal et al., 2003; Hansson et al., 2004, see Fig. 1, Protocol 3a). Cpeptide labeling of cells is an indication of proinsulin synthesis and can be demonstrated in cells that differentiate without FGF2 according to Protocol 4 (Blyszczuk and Wobus, 2004). Only 10

TABLE 1

\section{COMPARISON OF DIFFERENT PROTOCOLS AND PARAMETERS OF PANCREATIC DIFFERENTIATION OF MOUSE ES-DERIVED CELLS}

\begin{tabular}{|c|c|c|c|c|c|c|c|c|}
\hline $\begin{array}{l}\text { Differentiation } \\
\text { Protocol } \\
\text { (see Fig. 1) }\end{array}$ & References & $\begin{array}{l}\text { Insulin } \\
\text { mRNA }\end{array}$ & $\begin{array}{l}\text { C-peptide /insulin } \\
\text { co-expression }\end{array}$ & $\begin{array}{l}\text { In vitro } \\
\text { glucose } \\
\text { response }\end{array}$ & $\begin{array}{l}\text { In vitro C-peptide } \\
\text { secretion }\end{array}$ & $\begin{array}{c}\text { Rescue of diabetes } \\
\text { in animal models }\end{array}$ & $\begin{array}{c}\text { Electrophysiological } \\
\text { studies }\end{array}$ & $\begin{array}{l}\text { ELM studies } \\
\text { (insulin granules) }\end{array}$ \\
\hline \multirow[t]{3}{*}{ Protocol 1} & (Lumelsky et al., 2001) & + & n.d. & + & n.d. & - & n.d. & n.d. \\
\hline & (Rajagopal et al., 2003) & - & - & - & n.d. & n.d. & n.d. & n.d. \\
\hline & (Sipione et al., 2004) & + & $\begin{array}{l}\stackrel{+}{\text { different cell }} \\
\text { lations were stained }\end{array}$ & + & n.d. & - & n.d. & - \\
\hline Protocol 2 & (Miyazaki et al., 2004) & + & $\stackrel{+}{+}$ & - & n.d. & n.d. & n.d. & - \\
\hline Protocol $3 \mathrm{a}, \mathrm{b}, \mathrm{c}$ & (Hansson et al., 2004) & - & - & + & - & n.d. & n.d. & n.d. \\
\hline Protocol 3c & (Hori et al., 2002) & + & + & + & n.d. & + & n.d. & n.d. \\
\hline Protocol 4 & (Blyszczuk et al., 2003) & + & + & + & n.d. & + & n.d. & + \\
\hline Protocol 5 & (Blyszczuk et al., 2004) & + & + & + & n.d. & + & + & n.d. \\
\hline
\end{tabular}


to $15 \%$ of the insulin-positive cells were not labelled by C-peptide (see Fig. 1, Protocol 4, arrow) and the cells showed small fragmented nuclei. When selective factors (such as ITSFn) were omitted in Protocol 5, the number of such potential apoptotic cells could be reduced further (see Fig. 1, Protocol 5).

We conclude that the generation of ES-derived functional insulin-producing cells without applying lineage-selection (see Soria et al., 2000; Leon-Quinto et al., 2004) is dependent on suitable differentiation protocols and differentiation factors. We therefore propose that preselection of ES-derived undefined progenitor cells by ITSFn and FGF-2 before induction of pancreatic differentiation should be omitted.

\section{References}

BLYSZCZUK, P., ASBRAND, C., ROZZO, A., KANIA, G., ST-ONGE, L., RUPNIK, M. and WOBUS, A.M. (2004). Embryonic stem cells differentiate into insulinproducing cells without selection of nestin-expressing cells. Int. J. Dev. Biol. 48: 1095-1104.

BLYSZCZUK, P., CZYZ, J., KANIA, G., WAGNER, M., ROLL, U., ST ONGE, L. and WOBUS, A.M. (2003). Expression of Pax4 in embryonic stem cells promotes differentiation of nestin-positive progenitor and insulin-producing cells. Proc. Natl. Acad. Sci. USA 100: 998-1003.

BLYSZCZUK, P. and WOBUS, A.M. (2004). Stem cells and pancreatic differentiation in vitro. J. Biotechnol. 113: 3-13.

DEUTSCH, G., JUNG, J., ZHENG, M., LORA, J. and ZARET, K.S. (2001). A bipotential precursor population for pancreas and liver within the embryonic endoderm. Development 128: 871-881.

EDLUND, H. (1998). Transcribing pancreas. Diabetes 47: 1817-1823.

EDLUND, H. (2001). Developmental biology of the pancreas. Diabetes 50 Suppl. 1: S5-S9.

GRAHAM, V., KHUDYAKOV, J., ELLIS, P. and PEVNY, L. (2003). SOX2 functions to maintain neural progenitor identity. Neuron 39: 749-765.

GRITTI, A., COVA, L., PARATI, E.A., GALLI, R. and VESCOVI, A.L. (1995). Basic fibroblast growth factor supports the proliferation of epidermal growth factorgenerated neuronal precursor cells of the adult mouse CNS. Neurosci. Lett. 185: 151-154.

HACK, M.A., SUGIMORI, M., LUNDBERG, C., NAKAFUKU, M. and GOTZ, M. (2004). Regionalization and fate specification in neurospheres: the role of Olig2 and Pax6. Mol. Cell Neurosci. 25: 664-678.

HANSSON, M., TONNING, A., FRANDSEN, U., PETRI, A., RAJAGOPAL, J., ENGLUND, M.C., HELLER, R.S., HAKANSSON, J., FLECKNER, J., SKOLD, H.N., MELTON, D., SEMB, H. and SERUP, P. (2004). Artifactual insulin release from differentiated embryonic stem cells. Diabetes 53: 2603-2609.

HORI, Y., RULIFSON, I.C., TSAI, B.C., HEIT, J.J., CAHOY, J.D. and KIM, S.K. (2002). Growth inhibitors promote differentiation of insulin-producing tissue from embryonic stem cells. Proc. Natl. Acad. Sci. USA 99: 16105-16110.
JOSEPH-SILVERSTEIN, J., CONSIGLI, S.A., LYSER, K.M. and VER, P.C. (1989). Basic fibroblast growth factor in the chick embryo: immunolocalization to striated muscle cells and their precursors. J. Cell Biol. 108: 2459-2466.

KALCHEIM, C. and NEUFELD, G. (1990). Expression of basic fibroblast growth factor in the nervous system of early avian embryos. Development 109: 203215.

KIM, S.K. and MACDONALD, R.J. (2002). Signaling and transcriptional control of pancreatic organogenesis. Curr. Opin. Genet. Dev. 12: 540-547.

LEON-QUINTO, T., JONES, J., SKOUDY, A., BURCIN, M. and SORIA, B. (2004). In vitro directed differentiation of mouse embryonic stem cells into insulinproducing cells. Diabetologia 47: 1442-1451.

LUMELSKY, N., BLONDEL, O., LAENG, P., VELASCO, I., RAVIN, R. and MCKAY, R. (2001). Differentiation of embryonic stem cells to insulin-secreting structures similar to pancreatic islets. Science 292: 1389-1394.

MIYAZAKI, S., YAMATO, E. and MIYAZAKI, J. (2004). Regulated expression of pdx-1 promotes in vitro differentiation of insulin-producing cells from embryonic stem cells. Diabetes 53: 1030-1037.

OKABE, S., FORSBERG-NILSSON, K., SPIRO, A.C., SEGAL, M. and MCKAY, R.D. (1996). Development of neuronal precursor cells and functional postmitotic neurons from embryonic stem cells in vitro. Mech. Dev. 59: 89-102.

RAJAGOPAL, J. ANDERSON, W.J., KUME, S., MARTINEZ, O.I. and MELTON, D.A. (2003). Insulin staining of ES cell progeny from insulin uptake. Science 299: 363.

REYNOLDS, B.A. and WEISS, S. (1992). Generation of neurons and astrocytes from isolated cells of the adult mammalian central nervous system. Science 255: 1707-1710.

ROSSI, J.M., DUNN, N.R., HOGAN, B.L. and ZARET, K.S. (2001). Distinct mesodermal signals, including BMPs from the septum transversum mesenchyme, are required in combination for hepatogenesis from the endoderm. Genes Dev. 15: 1998-2009.

SEABERG, R.M., SMUKLER, S.R., KIEFFER, T.J., ENIKOLOPOV, G., ASGHAR Z., WHEELER, M.B., KORBUTT, G. and VAN DER, K.D. (2004). Clonal identification of multipotent precursors from adult mouse pancreas that generate neural and pancreatic lineages. Nat. Biotechnol. 22: 1115-1124.

SIPIONE, S., ESHPETER, A., LYON, J.G., KORBUTT, G.S. and BLEACKLEY, R.C. (2004). Insulin expressing cells from differentiated embryonic stem cells are not beta cells. Diabetologia 47: 499-508.

SORIA, B., ROCHE, E., BERNA, G., LEON-QUINTO, T., REIG, J.A., and MARTIN F. (2000). Insulin-secreting cells derived from embryonic stem cells normalize glycemia in streptozotocin-induced diabetic mice. Diabetes 49: 157-162.

WOBUS, A.M., ROHWEDEL, J., MALTSEV, V. and HESCHELER, J. (1994). In vitro differentiation of embryonic stem cells into cardiomyocytes or skeletal muscle cells is specificall y modulated by retinoic acid. Roux's Arch. Dev. Biol. 204: 36-45.

Received: November 2004

Reviewed by Referees: November 2004

Modified by Authors and Accepted for Publication: November 2004 